\title{
MYCELIAL GROWTH OF STRAINS OF PLEUROTUS OSTREATUS DEVELOPED ON AGAR AND ITS CORRELATION WITH THE PRODUCTIVITY IN PILOT PRODUCTION FARM
}

\author{
M. Sastre-Ahuatzi; M. Téllez-Téllez; G. Díaz-Godínez; A.M. Montiel-González; R. Díaz; C. Sánchez*
}

Laboratory of Biotechnology, Research Centre for Biological Sciences, Universidad Autónoma de Tlaxcala, Tlaxcala, Tlax., México.

Submitted: March 29, 2007; Returned to authors for corrections: July 16, 2007; Approved: July 24, 2007.

\begin{abstract}
Radial growth rate, intracellular laccases and proteases activities, and protein content were evaluated in five strains of Pleurotus ostreatus, grown on starch-based and glucose-based agar media containing different concentrations of the glucose analogue 2-deoxyglucose (2-DG). Productivity of the strains in pilot scale cultivation was also determined. The mycelium of four strains had approximately between 0.6 - to 3 -fold higher protein content when grown on glucose medium containing $0.01 \mathrm{~g} / \mathrm{L}$ of 2-DG than when grown on glucose medium. The radial growth rate and intracellular laccases activity of some strains showed a positive and a negative correlation with the productivity, respectively. These results suggest that the strains with high radial growth rate and low intracellular laccases activity on glucose without 2-DG, on starch without 2-DG or on glucose containing $0.01 \mathrm{~g} / \mathrm{L}$ of $2-\mathrm{DG}$ are highly productive in pilot production farm.
\end{abstract}

Key words: Pleurotus ostreatus, 2-deoxyglucose, laccases activity, proteases activity, mushroom production.

\section{INTRODUCTION}

The toxic compound 2-deoxyglucose (2-DG) has a molecular structure similar to glucose and can be taken up and metabolized by the cell as carbon source. As an analogue of glucose, 2-DG seems to affect the initial stages of carbohydrate metabolism and the stages of polysaccharide synthesis. The main aspects involved in the inhibition of cell metabolism by 2-DG are interference with sugar uptake, inhibition of hexokinase and inhibition of phosphoglucose isomerase. Other enzymes involved in different stages of glycolysis and in other pathways of the cell metabolism are also likely to be inhibited by 2-DG-6phosphate (8). 2-DG has often been used to select mutant microorganisms derepressed for sugars metabolism $(7,11,14)$. For example, with regard to citric acid production, the 2-DG resistant mutant strains of Aspergillus niger, were insensitive to catabolite repression $(4,10)$. The production of enzymes such as cellulases in Trichoderma reesei and glucoamylase in Rhizopus sp were improved by the induction of 2-DG resistance and the mutant strains were less sensitive to catabolite repression (15). It has been reported that strains of Saccharomyces cerevisiae that were resistant to 2-DG had enhanced fermentation (6). Similarly, strains of the edible mushroom Pleurotus ostreatus that were showed tolerant to 2DG were twice as productive in pilot production farm than those sensitive to this compound. A correlation between tolerance of P. ostreatus to 2-DG in starch medium and productivity was found (12). However, the biochemical aspects involved in such correlation were not studied. In this research, the effect of 2-DG on enzymatic activity and growth of five strains of $P$. ostreatus growing on agar media were studied. The productivity of the strains on wheat straw in pilot culture level was also evaluated.

\section{MATERIALS AND METHODS}

\section{Organism}

Five strains of Pleurotus ostreatus were studied: 58052, 38537, 201218 and 201216 from the American Type Culture Collection (Manassas, Virginia, U.S.A.) and 3526 from the Northern Regional Research Laboratory Collection (now the National Center for

*Corresponding Author. Mailing address: Laboratory of Biotechnology. Research Centre for Biological Sciences. Universidad Autónoma de Tlaxcala. Apartado postal 129, Tlaxcala, Tlax., CP 90000, México. Tel.: +52 2484815482. E-mail: sanher6@ hotmail.com 
Agricultural Utilization Research; Peoria, Illinois, U.S.A.). Stock cultures were grown on potato dextrose agar (PDA; J. T. Baker, Edo. de Mexico, Mexico) at $25^{\circ} \mathrm{C}$ in Petri dishes and stored at $4^{\circ} \mathrm{C}$. The inoculum was taken from the peripheral growth zone of a colony grown on PDA at $25^{\circ} \mathrm{C}$ for 7 days.

\section{Culture media}

Six different agar media containing mineral salts (12) and the following carbon sources were prepared: $10.5 \mathrm{~g} / \mathrm{L}$ maize starch (J. T. Baker, Edo. de Mexico, Mexico), $10.5 \mathrm{~g} / \mathrm{L}$ maize starch + 0.01 g/L 2-DG (SIGMA), $10.5 \mathrm{~g} / \mathrm{L}$ maize starch + 0.1 g/L 2-DG, $10.63 \mathrm{~g} / \mathrm{L}$ glucose (J. T. Baker, Edo. de Mexico, Mexico), $10.63 \mathrm{~g} /$ L glucose + 0.01 g/L 2-DG, $10.63 \mathrm{~g} / \mathrm{L}$ glucose + 0.1 g/L 2-DG. The $\mathrm{pH}$ of the medium was adjusted to 6.5 as previously reported (12). Petri dishes containing $30 \mathrm{~mL}$ of culture medium were used.

\section{Measurements of radial growth rate}

A $4 \mathrm{~mm}$ diameter mycelial plug was placed mycelium facedown on the center of the agar plates and the radial growth rate was measured by triplicate in separated Petri dishes. The contours of the colony were marked daily from the second to the seventh day of incubation. The radius of the growth was measured from the center to the contours of the colony by using a vernier (Mitutoyo). Radius versus time plots were analyzed by linear regression and the slope for each treatment recorded as the radial growth rate $\left(\mathrm{u}_{\mathrm{r}}\right)$ in $\mu \mathrm{m} / \mathrm{h}$ (12).

\section{Enzyme and protein assays}

For each treatment, $1 \mathrm{~g}$ mycelium scraped from the colonies developed for 7 days was ground in $10 \mathrm{~mL}$ of distilled water using a tissue grinder (Pyrex glass, Corning Inc., NY, USA). The resulting samples were centrifuged at $20000 \mathrm{x} g$ for $10 \mathrm{~min}$ at $2^{\circ} \mathrm{C}$ and the supernatant collected was the intracellular extract, in which laccase and protease activities, and protein content were evaluated. Alternatively, the biomass (X), as dry weight was determined by drying at $60^{\circ} \mathrm{C}$ to constant weight (AOAC 1990). Laccase activity was determined by changes in the absorbance at $468 \mathrm{~nm}$, using 2,6-dimethoxyphenol as substrate (1). Proteases activity was measured by changes in the absorbance at $280 \mathrm{~nm}$, produced by the release of aromatic aminoacids, using casein as substrate (5). One enzymatic unit (U) of either laccases or proteases was defined as the amount of enzyme which gave an increase of 1.0 unit of absorbance per min in the reaction mixture. The enzymatic activities were reported as U per gram of X (U/ $\mathrm{gX}$ ). Protein was measured by the Bradford method (2), using bovine serum albumin (SIGMA) as standard and reported as $\mathrm{mg}$ of protein per gram of $\mathrm{X}(\mathrm{mg} / \mathrm{gX})$. Each treatment was measured by triplicate in separated experiments.

\section{Productivity in pilot scale cultivation}

Pilot scale cultivation was carried out using cylindrical polyethylene bags filled with $5 \mathrm{~kg}$ of chopped ( $5 \mathrm{~mm}$ long approx.) and pasteurised (by immersion in water at $95^{\circ} \mathrm{C}$ for $1 \mathrm{~h}$ ) wheat straw. The substrate was drained out, cooled down at $25^{\circ} \mathrm{C}$ and then inoculated with mycelial spawn grown in sterile bottles filled with autoclaved wheat grains. Each strain was inoculated separately in 10 bags and incubated at $20^{\circ} \mathrm{C}$ in a dark room for 15 days approximately, and then moved to the production area at $15^{\circ} \mathrm{C}$ and humid atmosphere. Daily observations were made after two weeks in order to assess the day of emergence of the fruiting bodies on each bag. The productivity was evaluated as previously reported (12) and expressed as average daily mushroom production in $\mathrm{g}$ per $\mathrm{kg}$ of wheat straw.

\section{Statistical analysis}

Analysis of variances (ANOVA) and Duncan tests for mean values were done using the Statistical Analysis System program (13).

\section{RESULTS}

\section{Radial growth rate}

The effect of increasing concentrations of 2-DG on the $\mathrm{u}_{\mathrm{r}}$ of five strains of $P$. ostreatus, with glucose or starch as the main carbon source is shown in Table 1. All strains grew on starch medium and on glucose-media containing 0.00, 0.01 and $0.10 \mathrm{~g} /$ L of 2-DG. Three strains grew when 2-DG was added to starch medium at concentration of $0.01 \mathrm{~g} / \mathrm{L}$ (strains 38537 and 201218 from the ATCC and 3526 from the NRRL). No strain was able to grow on starch when $0.1 \mathrm{~g} / \mathrm{L}$ of $2-\mathrm{DG}$ was added.

The $\mathrm{u}_{\mathrm{r}}$ was significantly higher on starch medium than on glucose medium for ATCC58052 (307 and $255 \mu \mathrm{m} / \mathrm{h}$, respectively), ATCC201216 (254 and $171 \mu \mathrm{m} / \mathrm{h}$, respectively) and NRRL3526 (362 and $324 \mu \mathrm{m} / \mathrm{h}$, respectively), and showed a slight increase on starch compared to glucose for ATCC38537 (335 and 317, $\mu \mathrm{m} / \mathrm{h}$, respectively) and ATCC201218 (271 and $248 \mu \mathrm{m} / \mathrm{h}$, respectively). However, addition of 2-DG to starch medium resulted in a significant reduction in the $\mathrm{u}_{\mathrm{r}}$ for those strains which were able to grow on starch in the presence of 2-DG (Table 1). In contrast, addition of $0.01 \mathrm{~g} / \mathrm{L}$ of $2-\mathrm{DG}$ to glucose medium resulted in an increase in the $\mathrm{u}_{\mathrm{r}}$ in two strains (ATCC201216 and ATCC201218) and did not affect the $u_{r}$ in the other three strains. Strain ATCC201218 showed its highest radial growth rate on glucose-media containing 0.01 and $0.1 \mathrm{~g} / \mathrm{L}$ of $2-\mathrm{DG}$ (292 and $291 \mu \mathrm{m} / \mathrm{h}$, respectively).

Strain NRRL3526 had higher radial growth rates on starch medium, starch containing $0.01 \mathrm{~g} / \mathrm{L}$ of $2-\mathrm{DG}$ and glucose medium (362, 257 and $324 \mu \mathrm{m} / \mathrm{h}$, respectively), compared to the radial growth rates of the other strains on the same media, while strain ATCC201216 had the lowest $\mathrm{u}_{\mathrm{r}}$, compared to the other strains in all media.

\section{Intracellular protein content}

The effect of adding increasing concentrations of 2-DG on the intracellular protein content of five strains of $P$. ostreatus, 
using glucose or starch as the main carbon source, is shown in Table 2 . The mycelium of four strains had approximately between 0.6- to 3-fold higher protein content when grown on glucose medium containing $0.01 \mathrm{~g} / \mathrm{L}$ of 2-DG than when grown on glucose medium. However, strain NRRL3526 had slightly less protein content when grown on glucose medium containing $0.01 \mathrm{~g} / \mathrm{L}$ of $2-D G$ than when grown on glucose medium. Addition of $0.1 \mathrm{~g} / \mathrm{L}$ of 2-DG to glucose medium resulted in reduced protein content for all strains.

In general, mycelium grown on glucose-based media had higher protein content than mycelium grown on starch-based media, with the exception of strains NRRL3526 and ATCC38537. The mycelium of the strain ATCC201218 grown on starch containing $0.01 \mathrm{~g} / \mathrm{L}$ of 2-DG had the lowest protein content $(0.62 \mathrm{mg} / \mathrm{gX})$, whereas the mycelium of strain ATCC 58052 grown on glucose medium with $0.01 \mathrm{~g} / \mathrm{L}$ of 2 -DG had the highest protein content $(91 \mathrm{mg} / \mathrm{gX})$.

\section{Intracellular enzymatic activities}

Tables 3 and 4 show the effect of increasing concentrations of 2-DG on the enzymatic (laccase and protease) activities of five strains of $P$. ostreatus with glucose or starch as the main carbon source. No strain produced laccase when 2-DG was added to starch medium. Of all the strains, ATCC201218 grown on either starch or glucose medium had the highest laccase activities (126 and $166 \mathrm{U} / \mathrm{gX}$, respectively). NRRL3526 produced no laccases when grown on either starch media or glucose medium, and only low laccase activity ( 0.5 to $3 \mathrm{U} /$ $\mathrm{gX}$ ) on glucose medium with 2-DG added. Addition of $0.01 \mathrm{~g} /$ $\mathrm{L}$ of 2-DG resulted in decreased laccase production by all strains except NRRL3526, but addition of $0.1 \mathrm{~g} / \mathrm{L}$ of 2-DG increased laccase production by ATCC 38537 and ATCC201216 (Table 3).

Protease activity in the mycelium of strain NRRL3526 grown in glucose medium was higher $(32 \mathrm{U} / \mathrm{gX})$ than in other strains. Strain ATCC201218 had low protease activity in both starch and glucose media (1.8 and $9.9 \mathrm{U} / \mathrm{gX}$, respectively). Addition of $0.01 \mathrm{~g} / \mathrm{L}$ of 2-DG to glucose medium increased protease activity in 3 strains (ATCC38537, ATCC201218 and ATCC201216) and decreased it in two strains (ATCC58052 and NRRL3526), while addition of $0.1 \mathrm{~g} / \mathrm{L}$ of 2-DG to glucose medium or $0.01 \mathrm{~g} / \mathrm{L}$ of 2DG to starch medium reduced protease activity in all strains which grew (Table 4).

\section{Productivity of the strains}

The indices of productivity in pilot scale production for the five strains of $P$. ostreatus grown on wheat straw are shown in Table 5. Strains NRRL3526 and ATCC38537 had shorter

Table 1. Effect of 2-DG on the radial growth $(\mathrm{mm} / \mathrm{h})$ rate of several strains of Pleurotus ostreatus grown on different culture media.

\begin{tabular}{cccccccc}
\hline \multicolumn{2}{c}{ Culture media } & & \multicolumn{5}{c}{ Strains } \\
\cline { 1 - 4 } \cline { 5 - 7 } Carbon source & 2-DG added $(\mathrm{g} / \mathrm{L})$ & & ATCC 58052 & ATCC 38537 & ATCC 201218 & ATCC 201216 & NRRL 3526 \\
\hline Starch & 0.00 & & $307^{\mathrm{a}} \pm 26$ & $335^{\mathrm{a}} \pm 27$ & $271^{\mathrm{a}, \mathrm{b}} \pm 41$ & $254^{\mathrm{a}} \pm 37$ & $362^{\mathrm{a}} \pm 14$ \\
Starch & 0.01 & & no grow & $168^{\mathrm{b}} \pm 24$ & $133^{\mathrm{c}} \pm 28$ & no grow & $257^{\mathrm{c}} \pm 27$ \\
Starch & 0.10 & & no grow & no grow & no grow & no grow & no grow \\
Glucose & 0.00 & & $255^{\mathrm{b}} \pm 11$ & $317^{\mathrm{a}} \pm 34$ & $248^{\mathrm{b}} \pm 24$ & $171^{\mathrm{c}} \pm 35$ & $324^{\mathrm{b}} \pm 23$ \\
Glucose & 0.01 & & $256^{\mathrm{b}} \pm 17$ & $327^{\mathrm{a}} \pm 31$ & $292^{\mathrm{a}} \pm 16$ & $199^{\mathrm{b}} \pm 26$ & $316^{\mathrm{b}} \pm 16$ \\
Glucose & 0.10 & & $232^{\mathrm{b}} \pm 10$ & $307^{\mathrm{a}} \pm 16$ & $291^{\mathrm{a}} \pm 23$ & $177^{\mathrm{c}} \pm 12$ & $275^{\mathrm{c}} \pm 30$ \\
\hline
\end{tabular}

Means \pm standard error from three separate experiments. In the same column, results with the same letter are not significantly different $(\mathrm{p}<0.001)$

Table 2. Effect of 2-DG on the protein contents (mg/gX) of several strains of Pleurotus ostreatus grown on different culture media.

\begin{tabular}{cccccccc}
\hline \multicolumn{2}{c}{ Culture media } & & \multicolumn{5}{c}{ Strains } \\
\cline { 1 - 4 } \cline { 6 - 8 } Carbon source & 2-DG added (g/L) & & ATCC 58052 & ATCC 38537 & ATCC 201218 & ATCC 201216 & NRRL 3526 \\
\hline Starch & 0.00 & & $1.8^{\mathrm{d}} \pm 0.12$ & $34.5^{\mathrm{a}} 0.6$ & $0.89^{\mathrm{c}}$ & $5.3^{\mathrm{d}} \pm 0.21$ & $28.4^{\mathrm{b}} 0.7$ \\
Starch & 0.01 & & no grow & $14.6^{\mathrm{d}} \pm 0.1$ & $0.62^{\mathrm{c}}$ & no grow & $11.9^{\mathrm{d}} \pm 0.2$ \\
Starch & 0.10 & & no grow & no grow & no grow & no grow & no grow \\
Glucose & 0.00 & & $34.2^{\mathrm{b}} \pm 0.1$ & $16.4^{\mathrm{c}} \pm 0.8$ & $20.7^{\mathrm{b}} \pm 1.9$ & $34.7^{\mathrm{b}} \pm 3.0$ & $31.1^{\mathrm{a}} \pm 0.9$ \\
Glucose & 0.01 & & $90.6^{\mathrm{a}} \pm 3.4$ & $22.8^{\mathrm{b}} \pm 1.9$ & $33.4^{\mathrm{a}} 0.7$ & $40.8^{\mathrm{a}} \pm 1.8$ & $28.4^{\mathrm{b}} \pm 0.9$ \\
Glucose & 0.10 & & $15.2^{\mathrm{c}} \pm 0.5$ & $14.4^{\mathrm{d}} \pm 0.3$ & $18.5^{\mathrm{b}} 0.2$ & $9.44^{\mathrm{c}} \pm 0.4$ & $17.1^{\mathrm{c}} \pm 0.4$ \\
\hline
\end{tabular}

Means \pm standard error from three separate experiments. In the same column, results with the same letter are not significantly different $(\mathrm{p}<0.001)$ 
Table 3. Effect of 2-DG on the laccase activities (U/gX) of several strains of Pleurotus ostreatus grown on different culture media.

\begin{tabular}{cccccccc}
\hline \multicolumn{2}{c}{ Culture media } & & \multicolumn{5}{c}{ Strains } \\
\cline { 1 - 4 } \cline { 5 - 7 } Carbon source & 2-DG added (g/L) & & ATCC 58052 & ATCC 38537 & ATCC 201218 & ATCC 201216 & NRRL 3526 \\
\hline Starch & 0.00 & & $57.2^{\mathrm{b}} \pm 1.3$ & $6.1^{\mathrm{c}} \pm 1.50$ & $127^{\mathrm{b}} \pm 0.3$ & $78.4^{\mathrm{a}} \pm 2.88$ & 0 \\
Starch & 0.01 & & no grow & 0 & 0 & no grow & 0 \\
Starch & 0.10 & & no grow & no grow & no grow & no grow & no grow \\
Glucose & 0.00 & & $109.7^{\mathrm{a}} \pm 8.3$ & $14.5^{\mathrm{b}} \pm 0.4$ & $166.3^{\mathrm{a}} \pm 0.3$ & $51.7^{\mathrm{c}} \pm 0.66$ & 0 \\
Glucose & 0.01 & & $16.0^{\mathrm{c}} \pm 0.00$ & $4.51^{\mathrm{c}} \pm 0.17$ & $81.9^{\mathrm{c}} \pm 1.52$ & $23.1^{\mathrm{d}} \pm 1.0$ & $3.0^{\mathrm{a}} \pm 0.22$ \\
Glucose & 0.10 & & $16.4^{\mathrm{c}} \pm 0.66$ & $61.1^{\mathrm{a}} \pm 3.88$ & $20.6^{\mathrm{d}} \pm 1.1$ & $66.6^{\mathrm{b}} \pm 6.9$ & $0.52^{\mathrm{b}}$ \\
\hline
\end{tabular}

Means \pm standard error from three separate experiments. In the same column, results with the same letter are not significantly different $(\mathrm{p}<0.001)$

Table 4. Effect of 2-DG on the protease activities $(\mathrm{U} / \mathrm{gX})$ of several strains of Pleurotus ostreatus grown on different culture media.

\begin{tabular}{cccccccc}
\hline \multicolumn{2}{c}{ Culture media } & & \multicolumn{5}{c}{ Strains } \\
\cline { 1 - 4 } \cline { 6 - 8 } Carbon source & 2-DG added (g/L) & & ATCC 58052 & ATCC 38537 & ATCC 201218 & ATCC 201216 & NRRL 3526 \\
\hline Starch & 0.00 & & $6.0^{\mathrm{c}} \pm 0.94$ & $18.4^{\mathrm{a}} \pm 0.94$ & $1.8^{\mathrm{e}} \pm 0.44$ & $1.3^{\mathrm{d}} \pm 0.09$ & $10.5^{\mathrm{c}} \pm 0.10$ \\
Starch & 0.01 & & no growth & $2.0^{\mathrm{d}} \pm 0.26$ & $4.3^{\mathrm{d}} \pm 0.61$ & no growth & $4.5^{\mathrm{e}} \pm 0.32$ \\
Starch & 0.10 & & no growth & no growth & no growth & no growth & no growth \\
Glucose & 0.00 & & $25.4^{\mathrm{a}} \pm 1.57$ & $7.8^{\mathrm{c}} \pm 0.58$ & $9.9^{\mathrm{b}} \pm 0.78$ & $15.6^{\mathrm{b}} \pm 0.30$ & $32.0^{\mathrm{a}} \pm 0.55$ \\
Glucose & 0.01 & & $6.3^{\mathrm{c}} \pm 0.18$ & $16.4^{\mathrm{b}} \pm 1.3$ & $22.5^{\mathrm{a}} \pm 1.98$ & $20.6^{\mathrm{a}} \pm 0.19$ & $28.8^{\mathrm{b}} \pm 2.2$ \\
Glucose & 0.10 & & $7.8^{\mathrm{b}} \pm 0.41$ & $6.7^{\mathrm{c}} \pm 0.44$ & $8.1^{\mathrm{c}} \pm 0.24$ & $6.1^{\mathrm{c}} \pm 0.18$ & $6.2^{\mathrm{d}} \pm 0.19$ \\
\hline
\end{tabular}

Means \pm standard error from three separate experiments. In the same column, results with the same letter are not significantly different $(\mathrm{p}<0.001)$

fructification time (23 days) and higher productivities (21 and $17 \mathrm{~g} / \mathrm{kg} /$ day, respectively) than the other strains. Productivity for strain NRRL3526 was approximately $33 \%$ higher $(21 \mathrm{~g} / \mathrm{kg} /$ day) than for strains ATCC58052, ATCC201218 and ATCC201216 $(14 \mathrm{~g} / \mathrm{kg} /$ day $)$.

Table 5. Production performance of several strains of Pleurotus ostreatus when grown on wheat straw.

\begin{tabular}{lccccc}
\hline \multirow{2}{*}{$\begin{array}{l}\text { Production } \\
\text { parameters }\end{array}$} & \multicolumn{5}{c}{ Strains } \\
\cline { 2 - 6 } & ATCC & ATCC & ATCC & ATCC & NRRL \\
& 58052 & 38537 & 201218 & 201216 & 3526 \\
\hline Fructification $^{1}$ & $25^{\mathrm{b}}$ & $23^{\mathrm{c}}$ & $24^{\mathrm{bc}} \pm 1$ & $29^{\mathrm{a}} \pm 5$ & $23^{\mathrm{c}}$ \\
First harvest $^{2}$ & $37^{\mathrm{ab}}$ & $29^{\mathrm{c}}$ & $31^{\mathrm{bc}} \pm 1$ & $37^{\mathrm{a}} \pm 4$ & $30^{\mathrm{bc}}$ \\
Second harvest $^{2}$ & $61^{\mathrm{a}} \pm 3$ & $55^{\mathrm{b}} \pm 2$ & $51^{\mathrm{c}} \pm 1$ & $60^{\mathrm{a}} \pm 5$ & $44^{\mathrm{d}}$ \\
Productivity $^{\mathrm{a}}$ & $14^{\mathrm{c}} \pm 2$ & $17^{\mathrm{b}} \pm 2$ & $14^{\mathrm{c}} \pm 1$ & $14^{\mathrm{c}} \pm 3$ & $21^{\mathrm{a}} \pm 4$ \\
\hline
\end{tabular}

Means \pm standard error from three separate experiments. In the same row, results with the same letter are not significantly different $(\mathrm{p}<$ 0.001); ${ }^{1}$ Period of time in which the fruit bodies were observed (expressed in days); ${ }^{2}$ Day in which the mushroom was harvested; ${ }^{3}$ Average daily mushroom production in $\mathrm{kg}$ of fresh mushroom per $\mathrm{kg}$ of dry wheat straw.

\section{DISCUSSION}

Addition of $0.01 \mathrm{~g} / \mathrm{L}$ of 2-DG to glucose medium either increased or did not inhibit the growth cultures. In previous studies, stimulation of the $\mathrm{u}_{\mathrm{r}}$ was observed on glucose medium when 2-DG concentration was $0.01 \mathrm{~g} / \mathrm{L}$ (12). In this research, the $u_{r}$ of cultures grown on starch media was slower than the $u_{r}$ of cultures grown on glucose media when 2-DG was added to the media. The reason for this might be that starch is a complex carbon source. The $\mathrm{u}_{\mathrm{r}}$ of cultures grown on glucose medium containing $0.1 \mathrm{~g} / \mathrm{L}$ of 2-DG was slightly inhibited, which could be due to the attenuation by glucose of the inhibitory effect of 2-DG. In three strains (201218 and 201216 from the ATCC and 3526 from the NRRL), the proteases activity increased in glucose and glucose containing $0.01 \mathrm{~g} / \mathrm{L}$ of 2-DG. It might be correlated with the increase of the $u_{r}$ of such strains on these media, since the proteases play an important role in branching and hyphal tip elongation (3). The low amount of mycelial biomass obtained in cultures grown on starch medium might be a result of the low proteases activity in such cultures. It has been reported that in Agaricus bisporus and Lentinula edodes, the production of laccases increased as the mycelium developed and decreased at the beginning of the fructification, suggesting that laccases are primarily active during substrate colonization (9). The 
Mycelium of three strains (ATCC38537, ATCC201218 and NRRL3526) did not show laccases activity when grown on starch medium containing $0.01 \mathrm{~g} / \mathrm{L}$ of $2-\mathrm{DG}$, however, the culture medium showed a yellowish brown appearance. It might suggest that laccases and other oxidases were excreted into the medium. The mycelium of strain NRRL3526 did not show laccases activity when grown on starch medium, glucose medium and starch containing $0.01 \mathrm{~g} / \mathrm{L}$ of 2-DG. These results suggest that in this strain the laccases were also excreted into the culture media, which is correlated with the high $\mathrm{u}_{\mathrm{r}}$ showed on those culture media. In general, the strains showed a positive correlation between productivity in pilot scale production and the $\mathrm{u}_{\mathrm{r}}$ on agar media, since those highly productive strains also had a high $u_{r}$. However, laccases activity on agar media and productivity in pilot scale production showed a negative correlation, since those strains that had low intracellular laccases activity showed a high productivity. In general, addition of 0.01 $\mathrm{g} / \mathrm{L}$ of 2-DG to glucose medium increased the $\mathrm{u}_{\mathrm{r}}$, proteases activity, protein content and decreased the intracellular laccases activity. Growth of strains of $P$. ostreatus on either glucose or starch added with different concentrations of 2-DG, might be useful to detect highly productive strains. These results suggest that those strains that show a high $\mathrm{u}_{\mathrm{r}}$ and low intracellular laccases activity on glucose without 2-DG, on starch without 2-DG or on glucose containing $0.01 \mathrm{~g} / \mathrm{L}$ of $2-\mathrm{DG}$ are highly productive in pilot production farm. Indeed, more biochemical studies have to be carried out for a better understanding of the function of the enzymes in the mushroom metabolism. Knowledge of mushroom physiology is crucial to understand the processes that are involved in the growth of this organism, and develop methods to select industrially important strains.

\section{RESUMO}

\section{Crescimento micelial de cepas de Pleurotus ostreatus em ágar e sua correlação com produtividade em cultivo em escala piloto}

Avaliou-se o crescimento radial, as atividades de proteases e lacases e o conteúdo protéico de cinco cepas de Pleurotus ostreatus cultivado em agar à base de amido e à base de glicose contendo diferentes concentrações de 2-deoxiglicose (2-DG), um análogo da glicose. A produtividade das cepas em cultivo em escala piloto foi também determinada. Em quatro cepas o conteúdo protéico do micélio foi aproximadamente 0,6 a 3 vezes maior quando foram cultivadas em meio à base de glicose contendo 0,01g/L de 2-DG. O crescimento radial e a atividade de lacases apresentaram correlação positiva e negativa, respectivamente, com a produtividade. Esses resultados sugerem que as cepas com elevada taxa de crescimento radial e baixa atividade de lacases em glicose sem 2-DG, ou em amido sem 2-DG, ou em glicose com 0,01 g/L de 2-DG, são altamente produtivas em cultivo em escala piloto.

Palavras-chave: Pleurotus ostreatus, 2-deoxiglicose, atividade de proteases, cultivo de cogumelo

\section{REFERENCES}

1. Ardon, O.; Kerem, Z.; Hadar, Y. (1998). Enhancement of lignin degradation and laccase activity in Pleurotus ostreatus by cotton stalk extract. J. Microbiol., 44, 676-680.

2. Bradford, M.M. (1976). A rapid and sensitive method for the quantitation of microgram quantities of protein utilizing the principle of protein-dye binding. Anal. Biochem., 72, 248-254.

3. Deshpande, M.V. (1992). Proteinases in fungal morphogenesis. W.J. Microbiol. Biotechnol., 8(3), 242-250.

4. Kirimura, K.; Sarangbin, S.; Rugsaseel, S.; Usami, S. (1992). Citric acid production by 2-deoxyglucose-resistant mutant strains of Aspergillus niger. Appl. Microbiol. Biotechnol., 36, 573-577.

5. Kunitz, M. (1947). Crystalline soybean trypsin inhibitor. J. Gen. Physiol., 30, 291-310.

6. Lobo, Z.; Maitra, P.K. (1977). Resistance to 2-deoxyglucose in yeast: a direct selection of mutants lacking glucose-phosphorylating enzymes. Mol. Gen. Genet., 157, 297-300.

7. Montenecourt, B.S.; Eveleigh, D.E. (1979). Selective screening methods for the isolation of high yielding cellulase mutant of Trichoderma reesei. In: Brown, Jr. R.D.; Jurasek, L. (ed.) Hydrolisis of Cellulose. Mechanisms of enzymatic and Acid catalysis. Am. Chem. Soc., Washington pp. 289-301.

8. Moore, D. (1981). Effects of hexose analogues on fungi: mechanisms of inhibition and of resistance. New Phytol. 87, 487-515.

9. Ohga, S.; Smith, M.; Thurston, C.F.; Wood, D.A. (1999). Transcriptional regulation of laccase and cellulase genes in the mycelium of Agaricus bisporus during fruit body development on a solid substrate. Mycol. Res., 103, 1557-1560.

10. Parvez, S.; Rakoja, M.I.; Ahmed, M.N.; Latif, F.; Shahid, R.; Malik, K.A. (1998). Citric acid production from sugar cane molasses by 2 deoxyglucose-resistant mutant strain. Folia Microbiol., 43, 59-62.

11. Randez-Gil, F.; Sanz, P. (1994). Construction of industrial baker's yeast strains able to assimilate maltose under catabolite repression conditions. Appl. Microbiol. Biotechnol., 42, 581-586.

12. Sánchez, C.; Viniegra-Gonzalés, G. (1996). Detection of highly productive strains of Pleurotus ostreatus by their tolerance to 2deoxy-D-glucose in starch-based media. Mycol. Res., 100, 455-461.

13. SAS (1999). SAS user's guide, version 8.2 SAS Institute, Cary, N.C.

14. Sreenath, H.K.; Jeffries, T.W. (1999). 2-Deoxyglucose as a selective agent for derepressed mutants of Pichia stipitis. Appl. Biochem. Biotechnol., 77-79, 211-222.

15. Tani, Y.; Fuji, A.; Nishise, H. (1988). Production of raw cassava starch-digestive glucoamylase by a 2-deoxyglucose resistant mutants of Rhizopus sp. J. Ferment. Technol., 66, 545-551. 